\title{
OMÓWIENIA
}

\section{Konferencja międzynarodowa XVI Balcanicum, Nieformalne ruchy społeczne i religijne na Balkanach. Poznań, 3-4 listopada 2017 r.}

doi.org/10.14746/bp.2017.24.18

Szesnasta konferencja z cyklu Balcanicum została poświęcona zagadnieniu nieformalnych ruchów społecznych i politycznych w dziejach Bałkanów. Jej organizatorami byli Instytut Historii Uniwersytetu im. Adama Mickiewicza i Komisja Bałkanistyki przy Oddziale Polskiej Akademii Nauk w Poznaniu.

Do Poznania przyjechało dziewiętnastu uczonych z Polski i zagranicy, zajmujących się problematyką bałkańską: historycy, politolodzy, etnolodzy i filolodzy. W obradach uczestniczyli referenci z Macedonii i Rumunii, a także polscy bałkaniści z Łodzi, Katowic, Krakowa, Poznania, Olsztyna, Szczecina i Warszawy.

Wystąpienia obejmowały rozległą tematykę dotyczącą zmian społeczno-kulturowych, demograficznych i ruchów migracji na Bałkanach, od czasów starożytnych po współczesne. Problemy te rozpatrywano z perspektywy różnych dyscyplin naukowych. Pierwszy panel poświęcony był tematyce religii i herezji w czasach średniowiecznych, badacze z Uniwersytetu Łódzkiego przedstawili referaty na temat heterodoksyjnych ruchów dualistycznych na Bałkanach (dr Zofia Brzozowska), bogomilizmu (dr Małgorzata Skowronek), paulicjan i manichejczyków (prof. Teresa Wolińska) oraz herezji eutychiańskiej (dr Wawrzyniec Kowalski). Następnie poruszono problematykę dotyczącą obecności Lombardczyków w Cesarstwie Łacińskim (prof. Zdzisław Pentek, UAM), stosunków Wołochów i Romajów w okresie X-XII w. (prof. Jarosław Dudek, Uniwersytet Zielonogórski) i rewolty Muhy w historiografii rumuńskiej (mgr Mihai Ciobanu, Uniwersytet w Jassach). W ostatnim panelu przedstawiono referaty dotyczące zbójników, hajduków i kleftów w Europie Środkowej i na Bałkanach w czasach nowożytnych (prof. Ilona Czamańska, UAM) i obrazu tych środowisk w literaturze francuskiej (dr Wojciech Sajkowski, UAM).

Drugi dzień konferencji poświęcono dziejom współczesnym. Dr Nikola Minov i mgr Ivana Hadijevska z Uniwersytetu w Skopje przedstawili referat o geneyie ruchów feministycznych na Bałkanach, prof. Jarosław Rubacha z Uniwersytetu Olsztyńskiego poruszył kwestię roli Wewnętrznej Macedońskiej Organizacji Rewolucyjnej w bałkańskiej polityce Bułgarii (1893-1914), a prof. Jędrzej Paszkiewicz (UAM), scharakteryzował zaplecze społeczno-polityczne organizacji ustaszowskiej w czasie tworzenia jej struktur 1929-1933. Następnie przedstawiono współczesne zagadnienia związane z konfliktem etnicznym i kościelnym we wschodniej Serbii na przykładzie cerkwi w Malajnicy (prof. Ewa Nowicka-Rusek, Collegium Civitas), folklorem religijnym 
bektaszytów na Bałkanach (dr hab. Ewa Kocój, Uniwersytet Jagielloński) i działalnością wspólnoty salafitów w Bośni i Hercegowinie (prof. Dariusz Wybranowski, Uniwersytet Szczeciński). Ostatnie wystąpienia dotyczyły kwestii edukacji we współczesnej Grecji w kontekście feminizmu (prof. Dalibor Jovanovski, Uniwersytet w Skopje), ruchów ekologicznych w Bułgarii (prof. Tadeusz Czekalski, UJ), inteligencji belgradzkiej w dobie reżimu Josipa „Broz” Tity (dr Mateusz Sokulski, Uniwersytet Śląski) oray rumuńskiej terminologii religijnej w kontekście podziałów wyznaniowych (dr Tomasz Klimkowski, UAM).

Oprócz konferencji, 4 listopada w Poznaniu odbyło się także posiedzenie Komisji Bałkanistyki, działającej przy poznańskim Oddziale PAN. Podczas zebrania poszczególni członkowie Komisji przedstawili swoje obecne i planowane badania naukowe, związane z tematyką Bałkanów. Omówiono kierunki dalszych działań Komisji, w tym także plany dotyczące kolejnej konferencji z cyklu Balcanicum.

Wojciech Sajkowski 